\section{TEN YEARS OF GROWING EXCISED TOMATO ROOTS}

\author{
By DR. PHILIP R. WHITE \\ Roskefeller Insitute for Medical Research, Princeton, \\ Naw Jersey
}

$\mathrm{M}$ ARCH 1, 1943, marked the decennial anniversary of the starting of the first uninterrupted cultures of excised plant organs ${ }^{28}$. The root tip from which was derived the standard clone now used in all experimental studies on excised roots carried out in this laboratory was severed from its seedling parent on March 1, 1933. This root is still growing. From it have been made some 80,000 experimental cultures. In addition to these cultures for which increment data are available, large stocks have been maintained on which detailed records were not kept. The total measured increments represent many kilometres of growth; the theoretical increments ${ }^{28}$ amount to staggering figures (ca. $10^{2800}$ kilometres). It seems appropriate at this time to review briefly the history and behaviour of this clone.

Aseptic seeds of Bonny Best tomato were sown on sterile filter paper late in February 1933. When, on March 1, the seedling roots had attained a length of a centimetre or more, twenty-five of them were excised and each one placed in a separate flask. The nutrient ${ }^{24}$ was, as was soon discovered, not a very satisfactory one. Only one of the 25 roots grew. This was transferred on March 13 to fresh nutrient of a somewhat different and more satisfactory formula ${ }^{28}$. From this root, during an initial period of ten passages averaging 13 days per passage (127 days), a clone of 100 cultures was built up. This number was maintained through 42 subsecjuent passages of 7 days duration each (294 days), during which time each culture was measured daily. At the end of the fifty-second passage (421 days) the number of cultures in the measured stock was reduced to 25 and measurements were recorded thereafter only at the beginning and end of each weekly passage. Measurements of initial length, final length, number of branches, and length of longest branch together with notes on general behaviour were recorded for each culture.

Transplants were made wherever possible by severing a piece about $15 \mathrm{~mm}$. long from the apex of the culture ${ }^{4}$. Where, as occasionally happened, a culture became contaminated or the apex ceased to grow normally, this procedure, of course, became impossible. Such cultures were replaced where feasible by using the tip of a branch root which had already acquired its own dominance equal to that of the apex and was thus capable of equally rapid initial growth. This state is usually attained in tomato roots when the branch has reached a length of about $20 \mathrm{~mm} .^{\circ 4}$. When such branches were not available, fragments of the main root carrying one or more growing points which had not yet acquired this individual dominance were used as explants. Records were kept in such a way as to distinguish between these three categories: primary apices, secondary but dominant apices, and secondaries lack- ing established dominance, since cultures of the third category, in particular, usually showed a considerable lag in increment until some one branch acquired its own dominance.

A number of points of interest appear in the growth record for the ten years (512 passages). It has already been noted ${ }^{48}$ that the average growth-rates, in spite of their wide and apparently random week-to-week variation, nevertheless approximate a $\sin \theta$ curve when grouped in 26-week blocks beginning at the vernal and autumnal equinoxes. The average increment-rate for the entire ten years was $6 \cdot 73 \pm$ $0.15 \mathrm{~mm}$./cult./day. If we ignore the initial 20 passages which preceded the establishment of a standard procedure (average increment $3.05 \pm 0.42 \mathrm{~mm}$.) and begin with the autumnal equinox of 1933 (passage 21), there was no significant change in average incrementrate until the vernal equinox of 1938 (passage 254), that is, during the first $4 \frac{1}{2}$ years. Throughout this time the nutrient consisted of a modified Uspenski salt solution, sucrose, and yeast extract, and the original standard procedure was maintained. The 
of Robbins and Schmidt ${ }^{7-76}$ and Bonner ${ }^{78}$. This resulted in a sharp increase for the following year to a level of $12 \cdot 6 \pm 0.8 \mathrm{~mm}$. The increase here, over the previous mean rate, was $+6 \cdot 1+0 \cdot 8$, hence highly significant. This last nutrient has been used for too short a time (54 passages) to establish a new seasonal cycle. The results so far suggest, however, that the seasonal cycle may become much less pronounced in this nutrient. The impression given is that the great number of nutrient materials available and the more nearly optimal complex of environmontal conditions provide a buffer against the injurious effects of certain variables, especially temperature fluctuations ${ }^{4 \theta}$. This is presumably comparable to the means by which field conditions permit plants to survive and prosper under a range of variables to which they would succumb in the laboratory.

The random week-to-week fluctuations observed throughout the ten years are, for the most part, not capable of interpretation. The causes of a few are, however, known. The sudden drop in the 179th to 181st passages is such a one. This almost resulted in loss of the entire clone, for in the 181st passage, out of the 25 cultures only a single one, No. 12, survived. The entire clone was recovered and re-established from this single root tip, and even in this case the primary tip and all six of the secondary tips were killed, the meristem being recovered from nine newly established tertiaries. The cause of this near-tragedy was traced to a split in the condenser tube of the still used in preparing distilled water, allowing tap water to pass into the supposedly pure water supply. This was not city water but came from deep wells. The toxic agent is not definitely known but was probably a trace of lubricating oil shown to be present in the laboratory water supply in considerable quantity. When this condition was corrected the cultures recovered rapidly, and by the 184 th passage had been built up to full number (25) and a normal increment rate $(5 \cdot 3 \mathrm{~mm}$. as against the idealized average for that time of year of $c a \cdot 6 \cdot 6 \mathrm{~mm}$.). The sudden drop in the 228 th passage was correlated with and probably the result of a very sharp drop in room temperature ${ }^{48}$, such as sometimes occurs in mid-September. The windows of the laboratory had been left open follow. ing a very hot day, and a sudden fall in outdoor temperature was paralleled by that indoors, resulting in thorough chilling and excessive condensation on the walls of the flasks. Recovery from this was as abrupt as its incidence. The low general level between passages 279 and 287 coincided with a period of illness during which the clone was maintained by a relatively inexperienced assistant. The low level between passages 372 and 409 occurred in a period when the concentration of iron had been reduced as a result of experiments later shown to have been misinterpreted ${ }^{92}$. The sudden fall in passage 425 resulted from the accidental omission of iron from one batch of nutrient. Other fluctuations are, how. ever, unexplained.

The clone is still in excellent condition and shows every evidence of potential immortality. Cultures of this stock have been sent to the University of Missouri, the California Institute of Technology, New York University and Connecticut College, where they have been maintained through various periods, for special studies and for comparison with other elones of tomato roots.

Since this note is chiefly historical in import, I have appended a chronological bibliography of all papers dealing with the cultivation of excised root tips that have come to my attention, which gives, better than could any but a very extended discussion, a panoramic view of the development of this branch of plant tissue culture. I have purposely omitted references dealing exclusively with the cultivation of other tissues or organs, except for a few of the very early background papers, since these represent a separate though closely related field.

\section{CHRONOLOGICAL BIBLIOGRAPHY}

\section{2}

1. Haberlandt, G., Kulturversuche mit isolierten"Pflanzenzellen, Sitzungsber. Akad. Wiss. Wien, Math.Naturw. Kl., 111, 69-92 (1902).

2. Winkler, H., Besprechung der Arbeit G. Haberlandt's "Culturversuche mit isolierten Pflanzenzellen", Bot. Z., 60, 262-264 (1902).

\section{9}

3. Knudson, L., Viability of detached root-cap cells, Amer. J. Bot., 6, 309-310 (1919).

\section{2}

4. Kotte, W., Kulturversuche mit isolierten Wurzel. spitzen, Beitr. allg. Bot., 2, 413-434 (1922).

5. Kotte, W., Wurzelmeristem in Gewebekultur, Ber. bot. Gesel., 40, 269-272 (1922).

6. Robbins, W. J., Cultivation of excised root tips and stem tips under sterile conditions, Bot. Gaz., '73, 376-390 (1922).

7. Robbins, W. J., Effect of autolyzed yeast and peptone on growth of excised corn root tips in the dark, Bot. Gaz., 74, 59-79 (1922).

\section{3}

8. Chambers, W. H., Cultures of plant cells, Proc. Soc. Exp. Biol. and Med., 21, 71-72 (1923).

9. Robbins, W. J., and Maneval, W. E., Further experiments on growth of excised root tips under sterile conditions, Bot. Gaz., 76, 274-287 (1923).

\section{4}

10. Chambers, W. H., Tissue culture of plants, J. Missouri State Med. Assoc., 21, 55-56 (1924).

11. Robbins, W. J., and Maneval, W. E., Effect of light on growth of excised root tips under sterile conditions, Bot. Gaz., 78, 424-432 (1924).

\section{9}

12. Mayer, G. G., Der Einfluss Nährstoffzuführung auf das Längewachstum isolierter Wurzeln, Diss., Giessen (1929).

\section{0}

13. Dauphiné, A., Caractères histologiques de racines développées isolément, C.R. Acad. Sci., Paris, 190, $1318-1320(1930)$.

\section{1}

14. Felber-Pisk, I., Über das Wachstum isolierter Wurzeln, Sitzungsber. Akad. Wiss. Wien, Math.-Naturw. Kl., Abt. 1, 140, 67-82 (1931).

15. Heidt, K., Über das Verhalten von Explantaten der Wurzelspitze in nährstoffreien Kulturen, Arch. exp. Zellforsch., 11, 693-724 (1931).

16. White, P. R., Plant tissue cultures, the history and present status of the problem, Arch. exp. Zellforsch., 10, 501-518 (1931).

\section{2}

17. Gautheret, R. J., Sur la culture d'extremités de racines, C.R. Soc. Biol., Paris, 109, 1236 (1932). 